\title{
Beszámoló az "Egészségegyenlőtlenségek Magyarországon" rendezvényről
}

\author{
Report of the workshop titled Health inequalities in Hungary
}

\author{
Szerző: Uzzoli Annamária $\square$ \\ MTA Közgazdaság- és Regionális Tudományi Kutatóközpont Regionális Kutatások Intézete
}

Beküldve: 2019. 04. 11.

doi: 10.24365/ef.v60i2.458

Kulcsszavak: egészségegyenlőtlenség; kutatási projekt; szakmai találkozó

Keywords: health inequality; research project; workshop

A Magyar Tudományos Akadémia Közgazdaságés Regionális Tudományi Kutatóközpont Regionális Kutatások Intézetének (MTA KRTK RKI) Társadalmi egyenlőtlenségeket kutató horizontális múhelyei szervezett szakmai találkozót „Egészségegyenlőtlenségek Magyarországon” címmel 2019. április 1-én. Ennek helyszíne az MTA Humán Tudományok Kutatóháza volt Budapest IX. kerületében. A rendezvény célja a hazai egészségegyenlőtlenségkutatások releváns eredményeinek bemutatása, valamint több tudományterületet átfogó diskurzus kialakítása volt a téma szakértői, kutatói és a téma iránt érdeklődők között. A program két nagyobb részből állt: a délelőtti szekcióban egy jelenleg zajló kutatási projekt beszámolójára került sor, míg a délutáni szekció keretében az egészségegyenlőtlenségek okainak és következményeinek, megoldási lehetőségeinek széleskörű ismertetése történt meg különböző szakterületek képviselői által.

$\mathrm{Az}$ egészségegyenlőtlenségek vizsgálata gazdag múltra tekint vissza az MTA KRTK kutatási témái között, a szakmai találkozó megrendezése a Múhely 2015 óta létező rendezvénysorozatába illeszkedett. A rendezvényen összesen 12 előadás hangzott el, a résztvevők és az érdeklődők száma meghaladta a 30 főt.

\begin{abstract}
„A hozzáférés szerepe az egészségegyenlőtlenségekben - Egy kutatási projekt tapasztalatai" címet viselő délelőtti szekció koordinátora Uzzoli Annamária (MTA KRTK RKI) volt, aki kutatásvezetőként nemcsak felvezette és összegezte „Az egészségügyi ellátáshoz való hozzáférés szerepe az egészségegyenlőtlenségekben Magyarországon"ii nevű kutatási projekttel kapcsolatos fontosabb tudnivalókat, hanem részt vett a konkrét vizsgálati eredmények prezentálásában is. Előadásai így kitértek a kutatási projekt résztvevőinek, céljainak, kérdéseinek, feladatainak és munkaszakaszainak bemutatására, valamint a legfontosabb statisztikai eredmények közlésére, illetve a kutatás keretében elvégzett esettanulmány elsődleges tapasztalatainak szintézisére is. A kutatás a Nemzeti Kutatási, Fejlesztési és Innovációs Alap finanszírozásában valósul meg (K 119574 sz. projekt).

Az elméleti bevezető előadás során a rendezvény vendégei megismerték a kutatás elméleti hátterét („5A” modell), amelynek lényege, hogy a hozzáférés (Accessibility), az elérhetőség (Availability), az elfogadhatóság (Acceptability), a megfizethetőség (Affordability) és az elfogadhatóság (Appropriateness) összetevők több, egyidejűleg ható tényezőn keresztül befolyásolhatják az egészségügyi ellátás
\end{abstract}

'A horizontális múhely társadalmi és térbeli dimenziókban egyaránt vizsgálja az egyenlőtlenségeket.

ii A kutatási projekttel kapcsolatos további információk itt érhetők el: egeszsegugyihozzaferhetoseg.wordpress.com 
minőségét. A kutatás az ún. kevert módszertan alkalmazására épül, vagyis a kvantitatív és kvalitatív vizsgálati technikák kiegészítő jelleggel, magyarázó egymásra épülés során segítik a kutatási kérdések megválaszolását és a kutatási feladatok megvalósítását.

Az empirikus vizsgálatokban az egészségegyenlőtlenségek mérésére és a hozzáférés feltételeinek értelmezésére az akut szívinfarktus hazai megbetegedési és halálozási helyzetének feltárásával és az ellátás körülményeinek értékelésével került sor. A statisztikai vizsgálatok fő eredményei bizonyították az alapvető ellentmondásokat:

1) az akut szívinfarktus halálozási aránya ugyan jelentősen javult hazánkban, de még mindig igen magas a nyugat-európai országokhoz képest,

2) a heveny szívinfarktus halálozási arányának csökkenése ellenére sem mérséklődött jelentősen a szívinfarktus-megbetegedések aránya,

3) az európai szinten magas megbetegedési és halálozási arányszámok az országon belül számottevő területi különbségekkel párosulnak,

4) a területi különbségek az elmúlt években részben növekedtek.

A 2018 során Békés megyei egészségügyi intézményekben készült félig strukturált interjúk tapasztalatai információkat szolgáltattak az ellátáshoz való hozzáférés intézményi és egyéni befolyásoló tényezőiről. Legfontosabb megállapítás az volt, hogy az infrastrukturális egészségfejlesztések (pl. szívkatéteres központ létrehozása) lényeges javulást eredményez az infarktus utáni rövidtávú túlélési esélyekben, ugyanakkor a hosszú távú felépülés szempontjából még nagyobb hangsúlyt kell fektetni az eredményes rehabilitációra, pl. a betegoktatás erősítése révén.

Beke Szilvia (Gál Ferenc Főiskola Egészség- és Szociális Tudományi Kar) a Békés megyei helyi esettanulmány tapasztalatait ismertette előadásában, melyben kifejezetten az életmódváltás lehetőségeit és akadályait mutatta be. Tanulmányának egyik legfontosabb eredménye rávilágított arra, hogy az infarktuson átesett betegek számára nagy nehézségeket jelent a tartós életmódváltás, ami meghatározza hosszú távú túlélési esélyüket. Szintén fontos következtetése volt, hogy az integrált ellátás feltételeinek horizontális fejlesztése nagymértékben hozzájárulhat a rehabilitáció eredményességéhez.
Ennek egyik lehetséges formája lehet a háziorvosi praxisközösség kiterjesztése a kistelepülések egészségügyi alapellátásában.

Az empirikus kutatások adalékául szolgált Pál Viktor (Szegedi Tudományegyetem Természettudományi és Informatikai Kar Gazdaság- és Társadalomföldrajz Tanszék, SZTE TTIK GTF TSZ) által végzett tartalomelemzés, amely a hazai egészségegyenlőtlenségek csökkentésével kapcsolatban kialakult diskurzusok megismerésére irányult. Kvalitatív vizsgálatai felvetették azt az alapvető egészségpolitikai dilemmát, hogy a gazdasági racionalizálás és a progresszivitással együtt járó térbeli koncentráció, illetve a méltányos, mindenki számára területileg is hozzáférhető egészségügy kialakítása mennyire valósítható meg egyszerre. Néhány esettanulmány segítségével áttekintést adott arról is, hogy az elmúlt években a területi ellátás átszervezései, illetve új szempontok szerinti megszervezése hosszú távon hogyan szolgálhatják az ellátáshoz való hozzáférés javítását. A kvalitatív vizsgálatok eredményeit egészítette ki Kovai Cecília (MTA KRTK RKI), aki a szakirodalomfeldolgozás tapasztalatainak segítségével érintette a hozzáférés néhány társadalmi kérdését, elsősorban az esélyek/esélytelenségek vonatkozásában. A szakirodalmi előzmények alapján felhívta a figyelmet arra, hogy a társadalmi igazságosság érvényesülése az egészségügyi ellátásban különösen fontos szempont a hátrányos helyzetű, főként etnikai csoportok egészségi állapotának javításában. Szintén fontos következtetés hangzott el abban a tekintetben, hogy a hátrányos helyzetű területeken nemcsak a hozzáférés feltételeinek megteremtése járulhat hozzá az egészségegyenlőtlenségek csökkenéséhez, hanem az egyének és csoportok szociokulturális sajátosságainak előtérbe helyezése is.

A kutatás résztvevőinek előadásai után Uzzoli Annamária összegezte az elért eredményeket és tapasztalatokat, majd a releváns következtetések tükrében olyan szakpolitikai javaslatokat tett, amelyekben érvényesithetőek az ellátásszervezés területi optimalizációs szempontjai. Ennek egyik példája lehet az életmód-tanácsadásban a lakóhelyi adottságok érvényesítése, hisz város-vidék relációban alapvető különbség van az egészséges életmóddal kapcsolatos társadalmi normákban, szokásokban, lehetőségekben. A záró előadás egyúttal a kutatás aktuális feladatainak bemutatására is kitért, amely ismertette a jelenleg zajló szakértői interjúk főbb célkitűzéseit. 
Az érdeklődők és a meghívott vendégek számos kérdést fogalmaztak meg a délelőtti szekció végén, amelyek többek között a statisztikai vizsgálatokba bevonható indikátorokra, az interjútapasztalatok további feldolgozására, a társadalmi egyenlőtlenségekre vonatkozó értékelési szempontok erőteljesebb érvényesítésére, valamint az eredmények szakpolitikai hasznosítására vonatkoztak. A kérdések megválaszolását Nagy Erika (MTA KRTK RKI) moderálta.

$\mathrm{Az}$ „Egészségegyenlőtlenségek - okok, következmények, magyarázatok, megoldások" című délutáni szekció keretében különböző tudományterületek és egészségügyi szakterületek képviselői tartottak elméleti és gyakorlatorientált előadásokat az egészségegyenlőtlenséget érintő problémákról.

Kiss Norbert (Budapesti Corvinus Egyetem) témája részben kapcsolódott a délelőtt folyamán bemutatott kutatási projekthez, ugyanis kvantitatív módszerrel a teljesítményvolumen-korlátiii hatását elemezte a szívkatéteres beavatkozások alkalmazási gyakoriságára. A hatásvizsgálat több hasznos módszertani lehetőséget ismertetett, egyúttal felhívta a figyelmet a hasonló vizsgálatok korlátaira is. Legfontosabb eredménye, hogy a teljesítményvolumen-korlát megszűntetése után összességében nőtt az elvégzett szívkatéteres beavatkozások aránya az országban: elsősorban a katéterlaboroktól távolabb lakók részesültek nagyobb arányban ellátásban. A változások pozitív egészséghatásai (kórházi halálozás, visszavételi arány) rövidtávon még nem láthatók.

Az egészségegyenlőtlenségek okai és csökkentésük lehetőségei témakörben Csizmadia Péter (Nemzeti Népegészségügyi Központ, NNK) tartott áttekintést a fogalmi magyarázatok és kutatási irányzatok interpretálásán keresztül. Az előadás egyéb más között vázolta a kulturális tőke vagy az innováció szerepét az egyenlőtlenségek kialakulásában, valamint magyarázta az egészségben tapasztalható különbségeket a pszichoszociális elmélet vagy az életút-megközelítés alapján. Köztudott, hogy az egészségegyenlőtlenségek a társadalmi rétegződés következményei és nemcsak a közvetítő rizikófaktorok eredményei. Tény, hogy a jóléti államoknak sem tudták az anyagi és nem anyagi erőforrásokhoz való hozzáférésben jelentkező egyenlőtlenségeket kiküszöbölni, így az egészségegyenlőtlenségek megváltoztatása is radikálisabb újraelosztással lehetséges.

Az egészségegyenlőtlenségek csökkentésének egyik „eszköze” lehet az egészségfejlesztési irodák hálózata Magyarországon, amelyek új vagy inkább újszerú szereplői a népegészségügynek - emelte ki előadásában Szőke Katalin (NNK). A 117 egészségfejlesztési iroda többsége jelen támogatási rendszerben elsősorban a mentális egészség fejlesztésével foglalkozik. Tevékenységük révén cél az egészségi állapot javítása, a 65 év alatt bekövetkező halálozás csökkentése, és így az egészségegyenlőtlenségek mérséklése.

Bíró Anikó (MTA KRTK KTI, Egészség és Társadalom Lendület-csoport) az egészségügyi kiadásokban megjelenő egyenlőtlenségeket tanulmányozta hazai adminisztratív adatok alapján Prinz Dániellel (Harvard University) közösen. A járó-és fekvőbetegellátás kiadásai, illetve a vényköteles gyógyszertámogatás segítségével elemezték a munkapiacon aktív lakosság körében a jövedelmi helyzet és az egészségügyi kiadások közti kapcsolatot, valamint annak területi különbségeit. A Bíró Anikó által prezentált eredmények bizonyították, hogy akár $77 \%$-os különbség is lehet a legnagyobb és legkisebb kiadással rendelkező megyék között az egy főre jutó járóbeteg-szakellátási kiadásban, valamint azt is, hogy a jövedelem növekedésével az egészségügyi kiadások finanszírozása nem csak országos, hanem megyei szinten is nő, amely összefüggésnek további részletes vizsgálata a jövő feladata.

A magyarországi egészségügyi szakemberek migrációjának médiareprezentációja volt a fő témája Ilcsikné Makra Zsófia (SZTE TTIK GTF TSZ) előadásának, amelyben egy nemrég kezdődött kutatási projekt előzetes eredményeit adta közre. Az egészségügyi szakemberek külföldön történő munkavállalásának, országon belüli mobilitásának, illetve magánszektorba való vándorlásának az online médiában megfogalmazott okait és részbeni következményeit vizsgálta a tartalomelemzés módszerével, leginkább a térbeli-földrajzi tényezők megjelenésén keresztül. Egyik figyelemre méltó megállapítása, hogy a média értelmezésében a

\footnotetext{
iii A teljesítményvolumen-korlát (TVK) hazánkban 2004-ben került bevezetésre az egészségügyi ellátás jobb finanszírozhatóságának és tervezhetőségének érdekében. A Nemzeti Egészségbiztosítási Alapkezelő az egészségügyi szolgáltatók által a járóbeteg- és fekvőbeteg-szakellátás keretén belül elvégzett beavatkozásokat éves szinten, havi bontásban számolja el a szolgáltatók felé, azaz finanszírozza a betegellátás költségét. Az adott szolgáltató számára előzetesen megállapított TVK-n felül végzett beavatkozások költsége a szolgáltatót terheli.
} 
lokalitás szerepe elenyésző magyarázó tényező a jelenség létezésében.

Végül a konferencia hallgatósága ismételten aktívan vett részt az előadókhoz intézett kérdésekben, amelyek az egészségfejlesztési irodák lehetőségeire, a hátrányos helyzetú társadalmi csoportok egészségfejlesztési kihívásaira, vagy az egészségügyi szakemberek migrációjának következményeire irányultak.

Összességében elmondható, hogy a szakmai találkozó lehetőséget adott az egészségegyenlőtlenségek különböző szempontú megközelítéseinek megismerésére, a résztvevők közötti párbeszéd folytatására, és a kapcsolati háló megerősítésére. 